CLINICAL REVIEW

\title{
The Cronkhite-Canada syndrome
}

\author{
J. A. Cotterill \\ B.Sc., M.D., M.R.C.P.
J. P. Hughes
M.B., M.R.C.P.

\author{
J. L. DAY \\ M.D., M.R.C.P.
}
J. W. Paulley
M.D., F.R.C.P.

\author{
E. TURK \\ M.B., M.R.C.P. \\ Department of Medicine, Ipswich and East Suffolk Hospital, Ipswich, and \\ The General Infirmary, Leeds
}

\section{Summary}

The eighteenth patient and seventh survivor with the Cronkhite-Canada syndrome is described. A remission of 9 years followed gastrectomy and steroid therapy. Findings on seventeen other patients described in the literature are reviewed.

The histological features are discussed in detail. The jejunum, though macroscopically normal, showed oedema, increased vascularity and mucous gland secreting activity. The possible importance of this increased vascularity in the aetiology of this syndrome is discussed.

Cronkhite \& Canada (1955) described a syndrome of diffuse gastro-intestinal polyposis, alopecia, nail atrophy and hyperpigmentation. We report the eighteenth patient and seventh survivor with this syndrome.

\section{Case report}

\section{History}

The patient, a white 62-year-old male, was seen initially at the Royal Southern Hospital, Liverpool, in July 1961 . Nine months previously he had noticed that his finger nails had become brittle and deformed. Six months later he developed diarrhoea and colicky lower abdominal pain, opening his bowels four or five times daily and passing fluid or semi-solid offensive motions. Despite a good appetite he lost $28 \mathrm{lb}$ $(12.6 \mathrm{~kg})$ in weight and before admission he had noticed that his ankles were beginning to swell. There had been no alteration in body hair, pigmentation or loss of taste. There was neither a family history of gastro-intestinal polyposis nor of ectodermal abnormality.

\section{On examination}

His finger nails were noted to be brittle and deformed. His abdomen was distended and felt 'doughy' and a little ankle oedema was noted.

\section{Investigations}

Barium meal demonstrated an irregular outline at the pyloric end of the stomach with an abnormal mucous membrane pattern of the upper small bowel (Fig. 1). Barium enema showed marked alteration in the mucous membrane pattern throughout the colon suggestive of ulcerative colitis with no organic narrowing. Gastroscopy demonstrated a 'polypoid gastritis'. Sigmoidoscopy revealed a granular proctitis with 'masses of giant oedema showing in places as polyps'. Full blood count, urea, electrolytes and serum calcium were within normal limits. The abnormal laboratory investigations are shown in Table 1.

\section{Operation}

A laparotomy was performed in October 1961. Polyposis of the stomach and, in particular, its distal two-thirds was noted at operation together with small polyps in the duodenum and jejunum. The colon and pancreas appeared normal. A partial gastrectomy, leaving the proximal third of the stomach, was performed.

\section{Progress}

Diarrhoea and steatorrhoea persisted after operation and the patient became hypokalaemic. Therapy at this time included pancreatin, ascorbic acid, orovite, vitamin $A$, vitamin $\mathbf{B}_{12}$, codeine phosphate, calciferol and a high protein diet. Despite these 


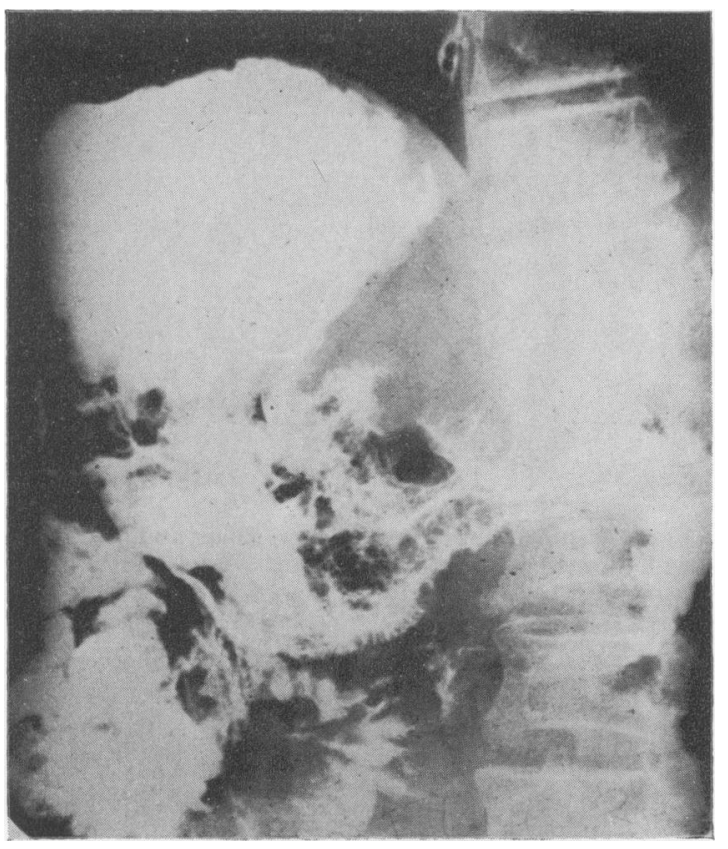

FIG. 1. Barium meal. 1961.

TABLE 1. Summary of abnormal investigations 1961-66

\begin{tabular}{ll}
\hline Investigation & Result \\
\hline Serum proteins & $5 \cdot 1 \mathrm{~g} / 100 \mathrm{ml}$ \\
Albumin & $2 \cdot 6 \mathrm{~g} / 100 \mathrm{ml}$ \\
Globulin & $2 \cdot 5 \mathrm{~g} / 100 \mathrm{ml}$ \\
Serum $\mathrm{B}_{12}$ & $35 \mathrm{pg} / \mathrm{ml}(\mathrm{normal}$ \\
& $\mathrm{range} 80-450 \mathrm{pg} / \mathrm{ml})$ \\
Faecal fat in g/day as stearic acid & \\
Before gastrectomy & $7 \cdot 2 \mathrm{~g}$ \\
After gastrectomy & $20 \cdot 7 \mathrm{~g}$ \\
29 December 1961 & $37 \cdot 7 \mathrm{~g}$ \\
4 April 1962 & $18 \cdot 75 \mathrm{~g}$ \\
1964 & $1 \cdot 7 \mathrm{~g}$ \\
1966 & $4.0 \mathrm{~g}$ \\
\hline
\end{tabular}

measures, 18 days after operation, the serum albumin had fallen to $1.9 \mathrm{~g} / 100 \mathrm{ml}$. In December 1961 prednisone $20 \mathrm{mg}$ t.d.s. was prescribed and this resulted in a dramatic improvement in his general condition and he had gained approximately $28 \mathrm{lb}$ in weight by March 1962 . His diarrhoea became less but he was still opening his bowels two or three times a day. By October 1962 his nails were much improved in appearance and barium enema and meal were now reported to be within normal limits.

He remained well until February 1964 when he was admitted to the Royal Portsmouth Hospital with an iron deficiency anaemia, his haemoglobin being $29 \%$ with positive faecal occult bloods. Serum albumin and calcium were normal. Faecal fat was $1 \cdot 7 \mathrm{~g} / 24 \mathrm{hr}$.
A barium enema showed roughening of the mucosa consistent with the presence of small polypi. He was transfused with 6 pints of blood and remained well until April 1966 when, resident in Suffolk, he complained of the gradual onset of paraesthesiae and weakness in his arms with pain in the thoracic and cervical spines. Walking had become increasingly difficult but he denied any diarrhoea or weight-loss and taste was normal.

The salient features on examination at this time included generalized muscle wasting most marked in the small muscles of the hand and weakness of the trunk and limbs most marked in the arms. Gross ataxia of the hands and arms due to sensory deficit was noted. Deep tendon reflexes were increased and both toes were extensor. His gait was ataxic but his Romberg was negative. Chvostek and Trousseau's signs were negative. The liver was enlarged to two fingers and smooth. Taste sensation was normal.

He was admitted for investigation in Ipswich. Full blood count, serum $B_{12}$, urea, electrolytes, calcium phosphate, alkaline phosphatase and serum proteins were within normal limits. The abnormal investigations are shown in Table 2.

TABLE 2. Summary of abnormal investigations 1967

\begin{tabular}{|c|c|}
\hline Investigation & Result \\
\hline $\begin{array}{l}\text { Serum folate } \\
\text { D-xylose absorption } \\
\text { SchiHing test }\end{array}$ & $\begin{array}{l}1.8 \mathrm{ng} / \mathrm{ml} \text { (normal range } 3-12 \mathrm{ng} / \mathrm{ml} \text { ) } \\
0.75 \mathrm{~g} \text { in } 5 \mathrm{hr} \text { after } 25 \mathrm{~g} \text { D-xylose } \\
2.1 \% \text { of cobalt-labelled vitamin } \mathrm{B}_{12} \\
\text { excreted in the urine in first } 24 \mathrm{hr} \\
\text { indicating malabsorption of the } \\
\text { vitamin }\end{array}$ \\
\hline Occult blood & Positive \\
\hline
\end{tabular}

Radiological examination of the cervical spine showed gross cervical spondylosis with spondylolisthesis and subluxation of $\mathrm{C} 3$ on $\mathrm{C} 4$ and, to a lesser extent, C4 on C5. A barium meal showed polypoidal appearances in the gastric remnant and followthrough examination demonstrated no obvious polyps in the small bowel or colon. A ${ }^{131}$ I polyvinylpyrrolidone test ( ${ }^{131}$ I PVP) was normal. A small bowel biopsy was performed. Gastroscopy was performed in 1969 and three hyperaemic oedematous polyps in the fundus of the stomach were seen.

\section{Pathology}

Histology of the stomach (Fig. 2) and of the rectum (Fig. 3) showed a loose, very vascular and oedematous stroma transversed by grossly dilated glands and lined by actively secreting goblet cells. Many of the cyst-like spaces contained mucin and appeared to communicate tortuously with the surface. It was noted that the lining epithelium was atrophic in those containing mucin (Fig. 2) as if the flow to the surface was obstructed. 


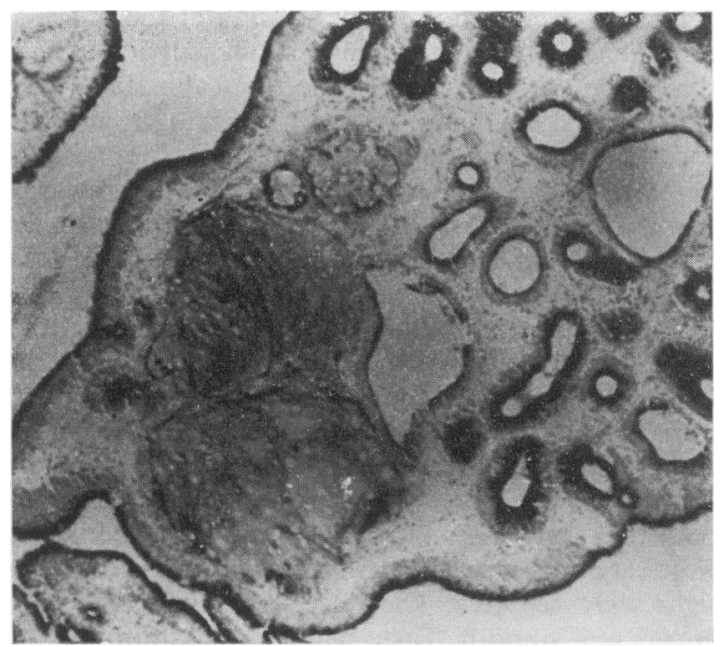

FIG. 2. Stomach. 1960. Shows distending cyst compressing the adjacent empty dilated gland with active staining epithelium and loose stroma. Alcian Blue, $\times 70$.

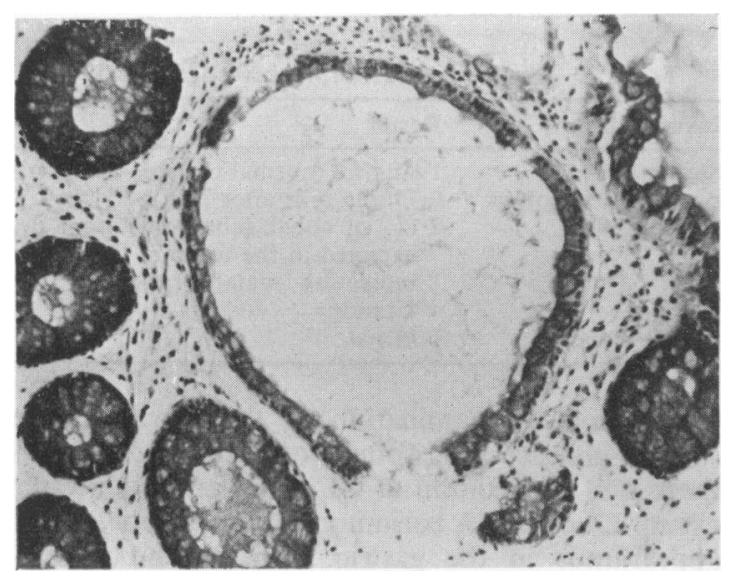

FIG. 3. Rectal biopsy. 1966. Lumen right top corner. Shows dilated cystic gland empty of mucin and dilated but no cystic glands in other areas. Alcian Blue, $\times 102$.

The small bowel biopsy (Figs. 4-6) under low power showed several normal finger-like villi and the routine report stated it was normal with much haemorrhage attributed to suction biopsy. However, on further inspection it was evident that most of the blood was intravascular and the villi and submucosa were copiously supplied with thin-walled vessels, while some of the glands showed dilatation and hypersecretion, but to a much lesser extent than the rectum and stomach. The nuclear arrangement of the villus cells was regular but the cytoplasm showed some vasculation. There was no increase in round cell

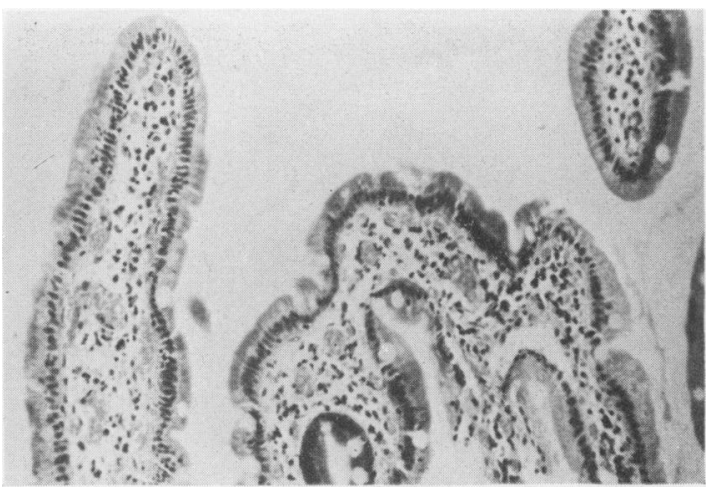

FIg. 4. Jejunal biopsy. 1966. Shows finger and leaf villi with normal nuclear arrangement. Vessels large and numerous. H \& E, $\times 102$.

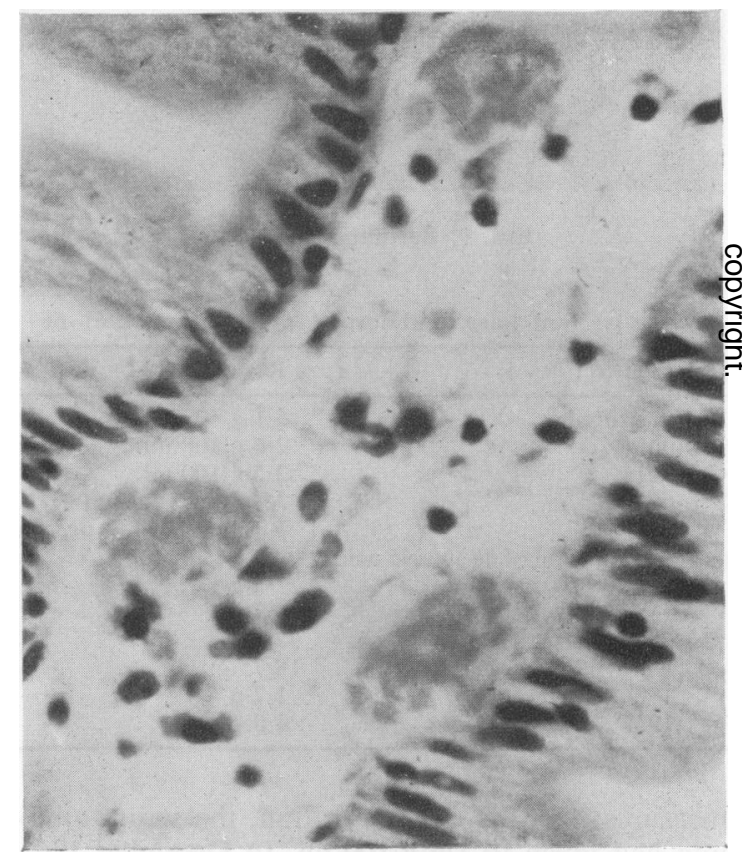

FIG. 5. Jejunal biopsy. 1966. Villus shows vacuolation of cytoplasm with normal nuclear arrangement. Abnormally vascular and loose stroma. H \& E, $\times 640$.

infiltration and the stroma appeared loose, possibly due to oedema.

\section{Discussion}

The clinical features of the Cronkhite-Canada syndrome in seventeen previously reported cases and in our own case are summarized in Table 3. Whilst McKusick (1962) lists at least six genetically distinct varieties of intestinal polyposis, the absence of a 


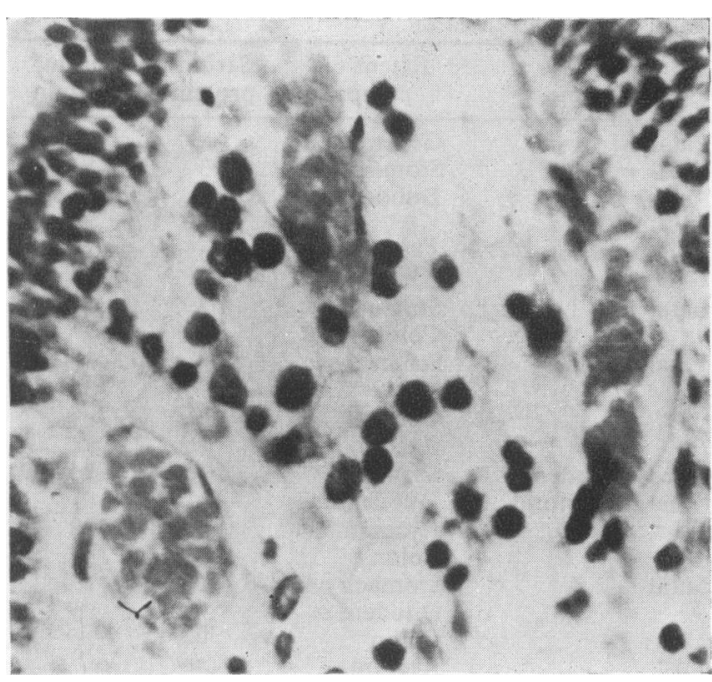

Fig. 6. Jejunal biopsy. 1966. Villus towards top. Very prominent vessels, clear cut endothelium. H \& E, $\times 560$.

family history in the Cronkhite-Canada syndrome is striking. The sex incidence shows a slight male preponderance (ten male and eight female cases). Diarrhoea, oedema, fits, alopecia and loss of taste have been common presenting features. In our patient nail changes were noted as the initial symptom. The duration of the illness has been very variable ranging from $2 \frac{1}{2}$ months to 10 years. Nine cases have ended fatally (Cronkhite \& Canada, 1955; Martini \& Dolle, 1961; Johnston et al., 1962; Ryall, 1966; Jarnum \& Jensen, 1966; Sakida \& Fukutomi, 1966; Da Cruz, 1967; Shibuya, 1972). Two patients died of unrelated causes (Cunliffe \& Anderson, 1967; Johnson et al., 1972). Malignant transformation was observed in polyps in two cases (Da Cruz, 1967; Shibuya, 1972). In all the other cases the histological changes have been of a simple adenomatous type. Spontaneous recovery has occurred in two cases (Ookita, Okuno \& Nakashima, 1958; Kennedy \& Hirson, 1961). The serum albumin has been low in most cases initially and Martini \& Dolle (1961) first demonstrated an abnormal ${ }^{131}$ I PVP excretion in their patients as evidence of a protein losing enteropathy. Later studies have confirmed an exudative enteropathy (Jarnum \& Jensen, 1966; Orimo, Fujita \& Yoshikawa, 1969; Johnson et al., 1972).

With regard to therapy it is apparent from Table 3 that three of the nine survivors have undergone major gastro-intestinal surgery whilst one patient died 4 days after a colectomy (Ryall, 1966). Thus, surgical removal of the major polyp-bearing areas of the alimentary tract, if feasible, may be indicated in severely affected patients. It is not clear why our patient responded to large doses of prednisone after operation, as this therapy did not seem to influence the degree of steatorrhoea at the time of clinical improvement. Johnson et al. (1972) have suggested that antibiotic therapy directed at a reduction in intestinal bacterial flora, hyperalimation and a polyand disaccharide-free diet may be useful in patients with this disorder.

The aetiology of the syndrome remains obscure. Our patient showed no significant pigmentary changes or hair-loss and his nails had returned to normal when we first saw him. The reported ectodermal changes are unlikely to be due to malabsorption as they are unlike any changes occurring in other malabsorptive states and the nail-changes in our patient preceded the diarrhoea by 6 months. The nail-changes are quite unlike those occurring in hypoparathyroidism and are therefore probably unrelated to a low serum calcium or candida infection of the nail. It has been suggested that the alopecia and nail-changes in patients with the CronkhiteCanada syndrome could represent alopecia areata and not an inherent component of the syndrome (Izumi, Rosato \& Shelley, 1970). The cause of the pigmentation is also unknown. The histoplasmin skin test, carried out because of gastro-intestinal polyposis in histoplasmosis, was negative in our case and a search for histoplasma and protozoa in the mucosa was also negative.

A loose stroma in the gastric polyps has been noted previously and thought to be due to oedema. This is also evident from the published photomicrographs of cases in the literature even where it escaped comment. It was a feature of the case reported here together with apparent overactivity of the mucous glands and exceptional vascularity of the mucosa. Vascularity of the order demonstrated in the photomicrographs came as no surprise to us after observing the plethora and succulence of the gastric polyps during gastroscopy. It seemed possible a qualitative or quantitative disturbance of mucin secretion from the glands of the stomach and rectum with obstructive cystic dilatation was a primary factor and any increased vascularity and oedema was probably secondary.

It was only when closer inspection showed comparatively normal jejunal villi without obvious signs of mucin hypersecretion to be just as vascular as their underlying submucosa, or the rectal and gastric polyps, that the alternative possibility that we might be dealing with a primary vascular disorder of the gastrointestinal mucosa had to be considered.

\section{Acknowledgments}

The authors wish to thank Dr E. N. Chamberlain, Mr R. W. Doyle and Professor J. C. Sloper for histological advice and Dr T. Shaw for the photomicrographs. 
TABLE 3. Summary of clinical findings in eighteen cases

\begin{tabular}{|c|c|c|c|c|c|c|c|c|}
\hline Case & Sex & Age & Initial symptom & Duration & Outcome & $\begin{array}{c}\text { Extent of } \\
\text { polyps }\end{array}$ & $\begin{array}{l}\text { Serum } \\
\text { protein }\end{array}$ & $\begin{array}{l}\text { Serum } \\
\text { albumin }\end{array}$ \\
\hline 1 & $\mathbf{F}$ & 42 & Diarrhoea & 8 Months & Fatal & Generalized & - & - \\
\hline 2 & $\mathbf{F}$ & 75 & $\begin{array}{l}\text { Diarrhoea } \\
\text { Pigmentation } \\
9 \text { years before }\end{array}$ & 17 Months & Fatal & $\begin{array}{l}\text { Stomach } \\
\text { Duodenum }\end{array}$ & $3 \cdot 3$ & $1 \cdot 1$ \\
\hline 3 & $\mathbf{F}$ & 69 & $\begin{array}{l}\text { Anorexia } \\
\text { Taste loss }\end{array}$ & $2 \frac{1}{2}$ Months & $\begin{array}{l}\text { Spontaneous } \\
\text { recovery }\end{array}$ & Generalized & & 'Normal' \\
\hline 4 & $\mathbf{F}$ & 71 & $\begin{array}{l}\text { Leg oedema } \\
\text { Diarrhoea }\end{array}$ & 18 Months & Fatal & $\begin{array}{l}\text { Stomach } \\
\text { Colon }\end{array}$ & $4 \cdot 3$ & $1 \cdot 6$ \\
\hline 5 & $\mathbf{F}$ & 51 & $\begin{array}{l}\text { Diarrhoea } \\
\text { Alopecia }\end{array}$ & 6 Months & Fatal & $\begin{array}{l}\text { Stomach } \\
\text { Ileum } \\
\text { Colon } \\
\text { Rectum }\end{array}$ & $5 \cdot 4$ & $3 \cdot 4$ \\
\hline 6 & $\mathbf{M}$ & 54 & $\begin{array}{l}\text { Abdominal pain } \\
\text { Diarrhoea }\end{array}$ & 6 Months & $\begin{array}{l}\text { Recovery after } \\
\text { hemicolectomy }\end{array}$ & $\begin{array}{l}\text { Stomach } \\
\text { Duodenum } \\
\text { Jejunum } \\
\text { Colon }\end{array}$ & $4 \cdot 15$ & 1.95 \\
\hline 7 & $\mathbf{F}$ & 58 & Taste loss & 10 Months & Fatal & $\begin{array}{l}\text { Stomach } \\
\text { Duodenum } \\
\text { Colon } \\
\text { Rectum }\end{array}$ & $4 \cdot 1$ & $1 \cdot 6$ \\
\hline 8 & $\mathbf{M}$ & 62 & $\begin{array}{l}\text { Taste loss } \\
\text { Alopecia } \\
\text { Nail loss }\end{array}$ & & Alive & $\begin{array}{l}\text { Rectum } \\
\text { Stomach }\end{array}$ & $3 \cdot 5$ & $1 \cdot 8$ \\
\hline 9 & $\mathbf{M}$ & 64 & $\begin{array}{l}\text { Diarrhoea } \\
\text { Weight loss }\end{array}$ & 7 Months & Fatal & $\begin{array}{l}\text { Stomach } \\
\text { Ileum } \\
\text { Colon } \\
\text { Rectum }\end{array}$ & $5 \cdot 5$ & $2 \cdot 3$ \\
\hline 10 & $\mathbf{M}$ & 60 & $\begin{array}{l}\text { Dyspepsia } \\
\text { Fit } 1962\end{array}$ & 9 Years & $\begin{array}{l}\text { Gastroenterostomy } \\
1957 \\
\text { Died } 1969\end{array}$ & $\begin{array}{l}\text { Stomach } \\
\text { Duodenum }\end{array}$ & $\begin{array}{l}6 \cdot 8 \\
6 \cdot 1\end{array}$ & \\
\hline 11 & $\mathbf{M}$ & 61 & $\begin{array}{l}\text { Diarrhoea } \\
\text { Weight loss }\end{array}$ & 4 Years & $\begin{array}{l}\text { Alive } \\
\text { Polygastrectomy } \\
1962\end{array}$ & $\begin{array}{l}\text { Stomach } \\
\text { Colon } \\
\text { Jejunum }\end{array}$ & $4 \cdot 8$ & $2 \cdot 0$ \\
\hline 12 & $\mathbf{M}$ & 64 & $\begin{array}{l}\text { Hair loss } \\
\text { Taste loss } \\
\text { Oedema }\end{array}$ & 5 Years & Alive & $\begin{array}{l}\text { Stomach } \\
\text { Small and } \\
\text { Large bowel }\end{array}$ & $4 \cdot 0$ & $2 \cdot 1$ \\
\hline 13 & $\mathbf{M}$ & 70 & $\begin{array}{l}\text { Diarrhoea } \\
\text { Pigmentation }\end{array}$ & 18 Months & $\begin{array}{l}\text { Died of unrelated } \\
\text { causes }\end{array}$ & $\begin{array}{l}\text { Stomach } \\
\text { Small bowel } \\
\text { Colon }\end{array}$ & $3 \cdot 3$ & 1.9 \\
\hline 14 & $\mathbf{M}$ & 62 & $\begin{array}{l}\text { Diarrhoea } \\
\text { Pigmentation }\end{array}$ & 15 Months & $\begin{array}{l}\text { Spontaneous } \\
\text { recovery }\end{array}$ & $\begin{array}{l}\text { Stomach } \\
\text { Colon } \\
\text { Rectum }\end{array}$ & $6 \cdot 6$ & $3 \cdot 3$ \\
\hline 15 & $\mathbf{F}$ & 68 & $\begin{array}{l}\text { Anorexia } \\
\text { Diarrhoea }\end{array}$ & 11 Months & Fatal & $\begin{array}{l}\text { Stomach } \\
\text { Colon }\end{array}$ & $4 \cdot 6$ & $2 \cdot 2$ \\
\hline 16 & $\mathbf{F}$ & 58 & Diarrhoea & 7 Months & Fatal & $\begin{array}{l}\text { Stomach } \\
\text { Duodenum } \\
\text { Colon } \\
\text { Rectum }\end{array}$ & 3.6 & $2 \cdot 1$ \\
\hline 17 & $\mathbf{M}$ & 60 & $\begin{array}{l}\text { Diarrhoea } \\
\text { Alopecia } \\
\text { Nail loss }\end{array}$ & 3 Months & $\begin{array}{l}\text { Fatal } \\
\text { after } \\
\text { colectomy }\end{array}$ & $\begin{array}{l}\text { Stomach } \\
\text { Small and } \\
\text { Large bowel }\end{array}$ & $5 \cdot 8$ & $3 \cdot 8$ \\
\hline 18 & $\mathbf{M}$ & 63 & $\begin{array}{l}\text { Nail changes } \\
\text { Diarrhoea } \\
\text { Weight loss } \\
\text { Oedema }\end{array}$ & 9 Years & $\begin{array}{l}\text { Alive } \\
\text { Partial } \\
\quad \text { gastrectomy }\end{array}$ & $\begin{array}{l}\text { Stomach } \\
\text { Small bowel } \\
\text { Colon } \\
\text { Rectum }\end{array}$ & 6.0 & $3 \cdot 5$ \\
\hline
\end{tabular}

Cases 1 and 2, Cronkhite \& Canada (1955); Case 3, Kennedy \& Hirson (1961); Case 4, Martini \& Dolle (1961); Case 5, Johnston et al. (1962); Case 6, Zdansky \& Riederer (1963); Case 7, Jarnum \& Jensen (1966); Case 8, Nishiyama et al. (1965); Case 9, Da Cruz; Case 10, Cunliffe \& Anderson (1967); Case 11, Manousos \& Webster (1966); Case 12, Orimo et al. (1969) Case 13, Johnson et al. (1962); Case 14, Ookita et al. (1958); Case 15, Sakida \& Fukutomi (1966); Case 16, Shibuya (1972); Case 17, Ryall (1966; Case 18, present case.

\section{References}

Cronkhite, L.W. JR. \& Canada, W.L. (1955) Generalized gastrointestinal polyposis; an unusual syndrome of polyposis, pigmentation, alopecia and onychotrophia. New England Journal of Medicine, 252, 1011.
Cunliffe, W.J. \& ANDERson, J. (1967) Case of CronkhiteCanada syndrome with associated jejunal diverticulitis. British Medical Journal, 4, 601.

GoMes DA CRUZ, G.M. (1967) Generalized gastrointestinal polyposis. An unusual syndrome of adenomatous poly- 
poses, alopecia, onychorotrophia. American Journal of Gastroenterology, 47, 504.

Izumi, A.K., Rosato, F.E. \& Shelley, W.B. (1970) Alopecia areata in association with intestinal polyposis. Acta Dermato-Venereologica (Stockholm), 50, 381.

JARNUM, S. \& JENSEN, H. (1966) Diffuse gastrointestinal polyposis with ectodermal changes. A case with severe malabsorption and enteric loss of plasma proteins and electrolytes. Gastroenterology, 50, 107.

Johnson, K.G., Soergel, K.H., Hensley, G.T., Dodd, W.T.\& HogaN, W.J. (1972) Cronkhite-Canada syndrome: gastrointestinal pathophysiology and morphology. Gastroenterology, 63, 140.

Johnston, M.M., Vosburgh, J.W., Wiens, A.T. \& Walsh, G.C. (1962) Gastrointestinal polyposis associated with alopecia, pigmentation and atrophy of the fingernails and toenails. Annals of Internal Medicine, 56, 935.

Kennedy, J.A. \& Hirson, C. (1961) A transient syndrome with Peutz-Jeghers features and ectodermal change. Proceedings Royal Society of Medicine, 54, 234.

McKusick, V.A. (1962) Genetic factors in intestinal polyposis. Journal of the American Medical Association, 182, 271.

Manousos, O. \& Webster, C.V. (1966) Diffuse gastrointestinal polyposis with ectodermal changes. Gut, 7, 374 .
Martini, G.A. \& Dolle, W. (1961) Menetrier-Syndrome. Polyadenomatosis des Magens mit Einweissverlust in den Magen-Darm-Kanal. Deutsche Medizinische Wochenschrift, 86, 2524.

Nishiyama, S., Mori, S. \& Harada, S. (1965) Gastrointestinal polyposis with universal alopecia, onychodystrophy and pigmentation of the skin. Archiv für Klinische und Experimentalle Dermatologie, 221, 144.

Ookita, H., OKuno, Z. \& NaKashima (1958) cited by Shibuya (1972).

Orima, H., Fujita, T., Yoshikawa, M., Takemoto, T., Matsuo, Y. \& NAKAO, K. (1969) Gastrointestinal polyposis with protein losing enteropathy, abnormal skin pigmentation and loss of hair and nails (Cronkhite-Canada syndrome). American Journal of Medicine, 47, 445.

RYALL, R.J. (1966) Polypoid hypertrophy of the gastrointestinal mucosa presenting as ulcerative colitis. Proceedings of the Royal Society of Medicine, 59, 614.

SAKIDA, T. \& Fuxutomi, H. (1966) cited by Shibuya (1972).

ShibuYa, C. (1972) An autopsy case of Cronkhite-Canada syndrome-generalized gastrointestinal polyposis, pigmentation, alopecia and onychotrophia. Acta Pathologica Japonica, 22, 171.

ZDANSKY, E. \& RIEDERER, J. (1963) Gastrointestinale polypose adenomatose mit hypoproteinaemic und ektodermalen storungen. Radiologia Clinica, 32, 254. 